\title{
Web-Enhanced Peer Feedback in ESL Writing Classrooms A Literature Review
}

\author{
Atif Elboshi ${ }^{1}$ \\ ${ }^{1}$ Memorial University of Newfoundland, Canada \\ Correspondence: Atif Elboshi, Memorial University of Newfoundland, Canada. \\ https://orcid.org/0000-0001-6235-3379 \\ Received: December 1, 2020 \\ Accepted: March 17, 2021 \\ Online Published: March 29, 2021 \\ doi: $10.5539 /$ elt.v14n4p66 \\ URL: https://doi.org/10.5539/elt.v14n4p66
}

\begin{abstract}
This paper aims to review literature on the impact of using web-based technology such as blogs and social networks to facilitate and promote peer feedback in ESL writing classrooms. It also investigates how giving and receiving comments from peer students can improve students' performance in writing as well as their critical thinking skills. A combination of 47 peer reviewed studies were included in this review. All these studies were found on MUN online library and the selection criteria I used in searching was studies that are relevant to: ESL writing, the importance of peer feedback and the role that web-based technology can do to facilitate peer feedback in ESL writing classrooms. The results showed that reflective assessment of peers' writing helps students develop their peers' and their own writing performance. They also stressed the role of web-based technology in providing a stimulating environment for students to reflect on peers' written work. However, some studies revealed the challenges that might affect using this technology such as students' reluctance, fear of sharing writing online and their sensitivity to being criticized publicly.
\end{abstract}

Keywords: ESL writing, peer feedback, Web-platforms

\section{Introduction}

In recent years, the student-centered pedagogy has emerged from the constructivist learning theory as the most effective way of teaching as opposed to teacher centered (Moate \& Cox, 2015; Otara et al., 2019; Vavrus, 2009). The main purpose of this approach is that it addresses the distinct needs and interests of the learners who work collaboratively and take responsibility for their own learning. These self-motivated students turn to be independent learners who direct their own learning and develop their communicative skills through discussions with their peers, "teaching one another" (Stephanie \& Lavoie, 2011, p. 353) with little or sometimes without help from the teacher. A salient feature of the student-centered approach is peer feedback, also referred to as peer review, which is used along with or in place of teachers' feedback (Dippold, 2009).

In English as a Second Language (ESL) writing classrooms, when students are assigned a writing task, it is necessary to inform them of their performance. However, in a teacher-centered classroom, this feedback is usually given by the teacher and as a result, students are merely passive receivers as the teacher is the one who determines the correctness of their work and responses (Kline, Letofsky \& Woodard, 2013). Whereas, in a typical student-centered classroom, teachers employ peer review in order to give their students the chance to assess and comment on each other's work. By applying this technique in the classroom, teachers change students' role from being solely receptive learners to become active participants who do not direct their responses and work to only please their teachers but to please themselves and their peers too. Buyse (2011) points out that when students work cooperatively to assess each other's writings, they are given the opportunity to: find real readers for their work, be confident writers and decision makers rather than relying passively on teachers' feedback.

It is also notable that peer review does not only encourage social interaction among students but also promote their critical thinking abilities to go beyond the regular cognitive processes of learning. This type of interaction among learners was emphasized in the findings of a study by Phillips (2011) who states, "social learning is academically and personally consequential for students, both in and out of school" (p. 680). It is remarkable that social interaction among students during their learning, helps them to acquire teamwork, diversity and communication skills which are reinforced by means of collaborative work. Apparently, students need these 
skills for improving their academic achievement and they also need them to be successful in the workplace afterwards.

With the many advantages peer feedback has in traditional classrooms, one may ask if feedback is done virtually by means of the internet, how beneficial it would be in facilitating learning for ESL writing students. Thus, this paper aims to answer this question and gain an understanding of the existing research about this topic. It also aims to identify factors that may affect using internet-based platforms in ESL classrooms for both teachers and learners. Finally, the article seeks to provide evidence on how students' performance in ESL writing can be improved so that both ESL writing teachers and designers of technology-enhanced learning environments are better informed. The significance of this review is that it extracts conclusions and findings that are supported by the majority of empirical studies. In addition to this, the review focuses on multiple factors that relate to the research question such as the psychological, social and academic factors instead of focusing on one factor as in the case of empirical studies.

\section{Methodology}

An electronic search of peer reviewed studies published between 2000 and 2019 was conducted. However, some older studies were also included for two reasons: firstly, their uniqueness in their examination and secondly, to provide more information of how peer review was looked at before the introduction of web-based technologies in education. The author used the online library of Memorial university of Newfoundland as a trusted source of peer reviewed articles and the key words used in this systematic literature search were peer review feedback, ESL writing classroom, peer feedback versus teacher's feedback and online or web-enhanced feedback in ESL writing. This latter search identified more than 69 articles addressing web-enhanced feedback but many of these articles were not mainly about ESL writing classes. Therefore, some amendments were done to the keywords for instance web-enhanced was replaced by blogs and online and that brought more studies for review.

\section{Literature Review}

\subsection{The Challenges of Teaching and Learning Writing in ESL Classrooms}

Writing is a purposeful activity in which the writer intends to deliver content to an audience by using letters of the alphabet, symbols and signs. It is one of the four basic skills of English language along with reading, listening and speaking. Hyland (2003) defines writing as a group of elements that have one perception or cognition. However, writing is believed to be the most difficult skill to teach for language teachers and to learn for students. For example, in a writing classroom, the difficulty that students face when writing does not only come from the fact that they need to have an adequate knowledge of grammar, punctuation, spelling, vocabulary, clarity, brevity, engagement, proofreading and revising but also the ability to use their social and personal experiences when they write. Elliot and Williamson (2013) emphasize the difficulty of writing by stating, "writing is among the most complex of human behaviors" (p. 2).

Because of the difficulty of writing, students usually feel demotivated toward writing classes. Buyse (2011) emphasizes this feeling, "teaching and learning writing skills is hardly ever the most motivating component of a language curriculum (p. 380). However, the challenges of writing in a second language (L2) are not comparable to that of writing in students' first language (L1). Francisco (2014) acknowledges two barriers that hinder writing in ESL classrooms, as she states, "in an English as Second Language class, the writing process has two more obstacles: the English language itself and the diversity of academic writing concepts that students already possess" (p. 335).

One of the most effective ways to overcome the difficulties that ESL students face when they write in ESL classrooms is motivation. Teachers have always found motivation to play an important role in making students accept the challenges of writing in English. Findings from a study by Abdulatif (2012) that aimed to investigate the practices and beliefs of English language teachers in Egypt, showed that teachers were reluctant to teach writing to their ESL students. Those teachers reported that they allocated only $1.47 \%$ of their teaching for the writing skill compared to $44.42 \%$ for teaching grammar. The study also found that Egyptian teachers of English ignored teaching writing in their classrooms and alternatively assigned writing tasks for students to be done at home. The teachers reported that students' resistance to participate in classroom writing activities and the lack of adequate time are two major reasons why they did not teach writing in their classrooms. It is notable here that the purpose plays an important role in learning writing. Because of the difficulty of writing and the fact that the final exams of English allocate a few grades for short paragraph writing, students were unwilling to learn or practice writing in the classroom. Conversely, because grammatical rules are given more grades in the final exam, nearly half of the classroom teaching time was given to grammar teaching. Thus, for ESL students to be motivated in writing classrooms, they should have a purpose. The most obvious purpose for these learners is usually to fulfill 
an academic requirement such as passing exams, or even "professional settings" (Hinkel, 2006, p. 111). Another purpose that could motivate ESL students to learn writing is to impress the teachers and/ or their peers.

\subsection{The Role of Feedback}

As writing is a creative work in which the students use their own ideas, beliefs and imagination to write a topic in the target language, it is necessary to tell these students about their performance regularly and whether or not it meets the course objectives. The most common way to do this is by correcting students' writing. The correction process of writing is usually done by the teacher who uses his red pen to comment on students' performance and grade it. In the past, when language teachers were affected by the grammar translation method in their teaching of a language, their main concern was on language accuracy rather than fluency. Therefore, whenever they corrected students' papers, they mainly focused on finding how effective the written work is in relation to students' mastery of morphology and syntax rather than the lexis of the language. This type of correction is still used today by many teachers as well as computer programs. Hyland and Hyland (2006) state, "in the automated context, writing is not evaluated as real interaction designed to achieve different communicative purposes with different audiences but as a performance artefact of student mastery of grammar, usage, and organization" (p. 95).

That being the norm of their correcting process, teachers rarely wrote comments or provided a holistic evaluation of students' written work to help them in their future writing. However, many educators regarded error -correction of grammar and spelling in a written text as a negative way to teach writing. For instance, in his reply to the findings of Chandler's study, Truscott (2004) points out that correcting grammatical errors has no benefit for students and giving students the chance to practice more writing is better than wasting time in correcting students' errors (p. 342).

Then in the 1980s the communicative approach was introduced as a response to progressivism (Matamoros-González et al., 2017). This new paradigm in teaching a foreign/ second language shifted students' role from being receptive learners to become active participants who are engaged in real life communication through authentic language. Consequently, teaching in ESL classrooms had to change from focusing primarily on the grammatical structure into the lexical domain of the language.

According to the communicative approach, teaching writing requires teachers to give their students the opportunity and freedom to express themselves and be able to create their writing the way that meets their expectations. Hinkel (2006) indicates that for L2 students to achieve proficiency in writing they need to have knowledge and skill in grammar and lexis. What Hinkel has pointed out here is realistic in the sense that students' writing is evaluated based on the correct structure of their sentences and the range of vocabulary used in these sentences. Without correct grammar, written texts can be illegible for the reader. Thus, in order to enhance students' performance in ESL writing, feedback is seen as an effective classroom strategy that encourages students to learn and improve their learning abilities (Hyland \& Hyland, 2006). To achieve this approach, writing teachers are expected to give their students regular feedback for their writing assignments. Hyland (2007) defines feedback as a reader's written comments on a student's written text that aims to help students improve their writing ability. It is important to mention that the corrective feedback can be written, verbal or mingled that aims to provide information to students about their learning (Ertmer et al., 2007).

The positive impact of feedback on students has been supported by a number of studies. For example, a study by Hosseiny (2014) that aimed to find out whether or not written corrective feedback has an impact on students' performance in writing, showed that students who did not receive any feedback from the teacher "had no opportunity to practice the structure" (Hosseiny, 2014, p. 672). Thus, for ESL students, feedback is essential to improve their writing performance and to guide them through their writing journey.

Teaching L2 writing through communicative focus comprises some instructional models such as content-based, problem- based, genre- based and many other models. One of the most important approaches of these is the genre approach. This approach enables students to analyze texts according to their types and purposes. Hyland and Hyland (2006) argue that for teachers to have a better knowledge of their students' communicative needs, written texts by ESL students should be analyzed and categorized according to their genres. In order to achieve this, teachers' feedback on students' work should not only mean to correct the spelling and grammatical errors in the texts but to determine what students need in order to become communicative writers. Teachers should also know that feedback has two basic roles: directive and expressive (Leng, 2014). Poehner and Infante (2017) point out that feedback tells the students to what extent they have developed their understanding and control over a specific area of the second language. 
Even though there are several types of feedback such as teachers', self-assessment and peer feedback, feedback from the teacher is still regarded as the most effective and reliable comments that assess students' performance in relation to the learning goals and outcomes. Whether these students are high or low achievers, in ESL writing classrooms they all need to receive regular, prompted and constructive feedback from their teachers. This feedback which is usually written regularly in students' writing notebook is in fact a record that monitors students' progress in writing throughout their academic year. A study by Lee (2010) to investigate how weblogs can develop language abilities of learners, revealed the inability of peer students to give their peers linguistic feedback for their written work. For this reason, students still believe that feedback from teachers is the only valid and trustworthy assessment of their development despite the change in teacher's role from being the sole source of information in the classroom to be a guide and a facilitator of students' learning.

However, teachers' feedback is disadvantageous for many reasons. First of all, it does not promote social interaction neither between the teacher and the students nor it does between the students themselves. Furthermore, by writing feedback for every student, learning becomes teacher-centered, and students are merely passive learners. Finally, this type of feedback does not promote students' critical thinking abilities because learners are not given the chance to evaluate neither their own nor their peers' writing.

\subsection{The Emergence of Peer feedback}

Although writing is a skill that takes students a long time to master (Rachmayani, Rifai, \& Rohadi, 2018), students' targeted audience is always the teacher. Hudelson (1988) states "writing involves taking into account varying audiences and purposes for what is being created" (p. 210). When students write, they know that the teacher is the one who will review, evaluate and grade their writing, consequently, their sole audience is the teacher. As a result of this, the content of their writing is meant to impress that teacher alone. However, if students are writing for other audiences such as their classmates or other people, the content and the style of their writing will vary accordingly. Whitney et al. (2012) emphasize the impact of audience on authors and the content of their writing, they state, "thus, active analysis and manipulation of audience choices and the consequences of those choices are one set of means by which authors become authors - that is, take agentic stances with respect both to audience and to content" (p. 395). Therefore, students' purpose of writing varies according to the targeted audiences. For instance, in classroom writing sessions, students usually write for grades or to impress their teacher and peer students (Weigle, 2011).

Albeit writing is an individual work that requires a student to use their knowledge and language skills to create a meaningful piece of writing, the socio-cultural contexts in which the student writes play an important role in enhancing their understanding of the language they learn (Lin \& Yang, 2011). Platt (1979) stresses the importance of the social context of learning and the role of schools to encourage students to socially interact among themselves. She also argues that a homelike atmosphere in a school would influence the quality of students' learning, especially their use of language. According to these views, in ESL writing classrooms students need to practice writing as a social activity in which they interact and respond to each other as opposed to an individual activity.

One of the main features of social interaction in a classroom is cooperative learning. Pair and group work strategies are amongst the well-known and the most used types of cooperative learning in a classroom. Hung (2019) indicates that cooperative learning creates an advantageous learning environment for peers to interact socially. In the same respect, Espasa et al. (2013) state, "collaborative work is seen as having potential to facilitate and stimulate learning" (p. 61). This is particularly crucial in ESL classrooms where difficulty of learning the second language makes students reluctant to participate effectively in any activities given to them. Thus, group and pair work can motivate students to actively take part in language activities and consequently improve their language skills and competencies. This is because students feel more relaxed and comfortable when they speak and work with each other. Platt (1979) illustrates this point "in small groups, children find it easy to talk and think, to gain response and understanding, and to feel safe" (p. 624). Despite this, many ESL students still prefer to ask and seek help from the teacher rather than their peers.

Working cooperatively is very useful in ESL writing classrooms as students need to discuss the topic of their writing before they start writing and after they finish. Students also need audiences who are nearly the same age and share the same interests to listen to and evaluate their written work. Additionally, many ESL students have difficulty in finding the appropriate vocabulary they need to express themselves and put their ideas into meaningful sentences. Therefore, working with peers would enable students to seek help from each other and this would improve their writing performance. Horowitz (1986) emphasizes the effectiveness of cooperative work in developing students' learning by stating, "our students surely can teach each other as much as or more 
than we can teach them" (p. 143).

Peer feedback or peer review is a typical feature of cooperative learning in a classroom. It is an instructional approach that is seen by many educators as an effective classroom strategy to enhance students' writing performance in ESL writing. For this type of learners, peer feedback is a principled way to assist their critical thinking abilities as well as their writing abilities. That is because students are not only expected to be receptive to peers' comments and evaluation of their written work but also to be able to evaluate and write feedback for their peers, too. While McConnell (2001) argues that peer review gives students the chance to practice cooperative learning in class, it is also beneficial for students to correct their peers' mistakes leaving the more difficult ones to teachers' feedback. In this regard, Silva and Moreira, (2003) go beyond this to claim that feedback which is given by peer learners can be more efficient than a feedback given by a busy teacher.

From another perspective, peer feedback, which is a social interaction among students, can be placed within the socio-cultural context of the Vygotskian theory (SCT). According to the Vygotskian socio-cultural theory, the social environment plays an important role in developing the learning abilities of students in another language (Poehner \& Infante, 2017). A study by Lakarnchua and Wasanasomsithi (2013) found that some online peer feedback comments were not related directly to their peers' writing but could be categorized as social interactive chatting which shows how web platforms such as blogs can motivate students to take part in the writing activities. In addition to its social benefits, peer feedback gives students the opportunity to acquire higher-level thinking skills. This is because giving feedback requires students to analyze, criticize, evaluate peers' written work. All these actions are categorized under the highest cognitive level of complexity according to Bloom's taxonomy.

Like in other types of classrooms, peer feedback in ESL classrooms can be implemented with and without the use of technology. In classrooms where technology is not available students give feedback by writing in their notebooks or on their peers'. One of the drawbacks of this method is that not every student in the classroom is able to read all the feedback or comment on their peers' work. In contrast to this traditional method, web-based blogs and social networks provide a greater chance for all students to read all the comments given by their peer students and comment on them. What's more, students are not restricted by the time limit as in physical classrooms and therefore can view and give their review on their pace.

In another way, peer feedback can be a good way to assist writing teachers who are already overloaded with a lot of responsibilities inside and outside the classroom. For example, the expanding number of students in many classrooms, especially in developing countries in which the number of students exceeds 40 in one classroom, makes it hard for writing teachers to give feedback for every student on every writing task he/she does. This difficulty was emphasized by Cuseo (2007) who indicates that, large class-size, "reduced frequency of instructor interaction with and feedback to students" (p. 2). Likewise, the negative impact of large classrooms on students' academic achievement was emphasized by Pascarella and Terenzini (2005) who indicate that class size correlates negatively on students' grades.

\subsection{The Role of Web-Based Technology in Facilitating Peer Feedback}

During the last two decades, technology-enhanced learning systems were introduced to support the learning and teaching processes. Many online educational platforms could easily be accessed and used by learners and teachers by means of computers, tablets and smartphones. Such platforms are social media networks, web-based blogs and many other platforms which have produced a lot of educational material (Silva \& Moreira, 2003). Because of the rapid advancement in information technology around us, modern students rely much on the internet to the extent that they are described as the "Internet Generation" (Buyse, 2011, p. 377).

Results from a study by Afroz (2016) concluded that there is a high level of internet addiction among university students. These students spend hours and hours every day playing online games, chatting, watching films or listening to music. In other words, the internet has become an essential part of their daily life. Therefore, it becomes logical for teachers to use the great features of the internet to facilitate their teaching as well as students' learning. This is not only because of the huge number of authentic materials and activities the internet hosts but also due to its availability in and outside schools which makes it easier for students to learn at any time and from anywhere.

While web-based platforms provide support for learners to acquire knowledge in all fields of study, its support for language learning, especially writing, is remarkable. According to Warschauer and Healey (1998) the internet has added a new function for the computer from just displaying and processing information to become a tool for communication. Since language education is based on learning the language as a means of communication and personal development, using internet-based technologies can be an effective way to facilitate students' 
communication in the target language.

Similarly, Lin (2011) stresses the role of the internet and computer-mediated communication as a powerful educational tool to facilitate writing in ESL classrooms. For example, the implementation of using social networks and web blogs on ESL writing students is very constructive for students' progress as they are given the chance to use the target language meaningfully to chat, respond and interact with each other at their convenience and in a way that is easier than in a classroom setting where they are restricted by the curriculum they must learn, and the limitation of time allocated for the writing class.

That being said about the importance of using the internet-based technology in ESL writing classrooms, peer review is one of the fields that could become a more effective tool if done by means of the web. In this type of online environment, learners usually get support from an expert who is usually a peer student or the teacher himself. This expert helps students to get engaged in their tasks through scaffolded learning (Espasa, Guasch, \& Alvarez, 2013). As Hyland and Hyland (2006) indicate, scaffolding according to psychologists Vygotsky and Burner reinforces the importance of interactions with peer students and /or the teacher to shift students' current level of performance into their potential performance in order to be independent learners. Similarly, Taylor, Ryan and Pearce (2015) indicate that scaffolding which is incorporated in self and peer review tasks helps students to learn and use reflective skills successfully. This suggests that explicit scaffolding is necessary to help students provide analytical review of their peers' work.

The role of web-based technology to facilitate peer feedback was stressed by Espasa et al. (2013) who point out that when peer feedback is done online, it provides a typical written communication environment in which the difficulty of face-to-face communication found in a physical classroom is eliminated or at least reduced. In the same respect, findings of study by Papadopoulos, Lagkas and Demetriadis, (2012) reinforce the advantageous phase of using web-based platforms to give and receive feedback. The participants who are undergraduate students reported that writing multiple reviews for their peer students helped them both academically and socially (p. 192). One of the significant features that is specific to web-enhanced peer feedback is writing multiple feedback. To illustrate this point, nearly in all ESL classrooms, teachers make students exchange their writing papers in order to review and comment on each other's work. In this way a student is only exposed to one written work and he has to respond to it individually. Because of the limited time of the class, it is impossible for everyone's written paper to be reviewed by the whole class. Therefore, the feedback given is a sole response to the writing and it could be inappropriate or invalid but when peer feedback is done online the receiver gets multiple feedbacks from other students. The wide range of the feedback given by different students is more authentic and valid than an individual feedback by one student.

Another advantage of using web-based platforms to give and receive feedback is the feasibility of seeing and commenting on all peers' writings and feedback in one place. This is nearly impossible to be done in the traditional classroom as the teacher has to print a copy of students' written paper and distribute it to the whole class to comment on. In this regard, Silva and Moreira (2003) state, "although possible, it is too complicated to print assignments and reviews on paper for every student in a class" (p. 3). The authors also point out that the "manual process" of giving peer feedback reduces its effectiveness due to the long time it takes to be implemented (Silva \& Moreira, 2003). In addition to this, printing students' work is costly for the school budget in addition to being environmentally unfriendly.

One of the important aspects of online feedback is the use of the target language. On web-based platforms such as blogs, students have to use English language to communicate with each other. One of the problems that nearly all ESL teachers notice and complain of in their classrooms is that students tend to use their first language when they work face to face. Undoubtedly, students are more comfortable when they use their first language, but this will not help them in their acquisition of English language as they are not exposed to the structures of the target language. Whereas, on online platforms ESL students have to use English as the language of communication when they comment on each other's work. It is unlikely for them to use their first language because their teacher is monitoring and will not allow them to use it here. Another important feature of using English by students online is the use of writing to communicate with each other. Thus, by writing comments for their peers, students are improving their writing abilities, too. Not only that, but also the type of language students use on online platforms is different from the language they usually use in the classrooms.

To illustrate this point; a study carried out by Davoli, Morani and Eklundh (2009) reported that, although using web-based platforms to give peer feedback had a positive as well as a negative impact on students, the participants revealed that their writing style has become more formal because online platforms are public and open to all audiences. They also indicated that platforms helped them to be more spontaneous and natural writers. 
In the same regard, Letofsky and Woodard (2013) indicate that both the writer and reviewer are constrained to the language structures they have learned through their interactions with their teacher and peer students. What is understood here is that web-based platforms will not only facilitate communication among ESL learners but promote students' language style as well.

For online platforms to be an effective environment for promoting ESL writing learning, they have to provide students with a realistic meaningful communication in which language skills are integrated. Hinkel (2006) stresses the importance of offering such type of communication by stating, "in meaningful communication, people will employ incremental language skills not in isolation but in tandem" (p. 113). A good example of a realistic meaningful communication is peer review. Since students will use the web to post their writing and reflect on peers' writing and comments, they communicate realistically and meaningfully. Thus, it is teachers' responsibility to ensure that online discussions are meaningful and that the feedback they give aims to develop their own and their peers' writing abilities which is important for their academic achievement. Horowitz (1986) stresses this point noting that, "teaching students to write and revise according to the demands of an audience is useless unless those demands are realistic simulations of academic demands (p. 142). In this way, students are likely to be motivated to participate effectively over these online platforms especially because it develops their language learning.

In contrast to physical classrooms, online platforms provide students with the chance to revisit the web page many times to review and read what has been written there. This unique feature cannot be provided elsewhere because the content of the web page is always there and can be reached from anywhere even for those who did not attend the classes. What is more, the availability of online discussion is very beneficial for students who normally forget most or parts of what they have learned after a short time. Buyse (2011) points out that students forget more than half of the structures they learned in less than 24 hours unless they are exposed to them again. In this respect, ESL students, especially struggling ones, are likely to take less than 24 hours to forget what they learned due to their lack of the basic skills of the language as well as their inability to participate effectively in classroom activities. Munoz (2012) states, "intensive exposure environments probably implicit L2 learning processes to a greater degree than regular limited classroom exposure" (p. 142). Thus, with continuous exposure to the learning materials over the web, students are likely to improve their language skills as they will revisit the online platform several times to see what their peers have written and comment on them which would give them a reason and motivation to use the language meaningfully. Dippold (2009) indicates that exposure to different opinions and views from larger audiences improves learners' critical thinking abilities.

Finally, it is important to mention that students' exposure to the learning materials online does not only improve their language skills but even their technology awareness. Wildner (1999) points out, "students have long-term exposure to technology, develop a habit of life-long learning about technology, and learn to implement and model technology within subject matter courses" (p. 232).

\subsection{Implications and Challenges of Using Web-Enhanced Peer Feedback}

Although a growing body of research suggests that peer feedback in ESL writing classrooms is very advantageous for students' autonomy, academic performance and personal development, many teachers and students still do not believe in the effectiveness of using it in their classrooms (Rachmayani, Rifai \& Rohadi, 2018; Rollinson, 2005). While teachers think that it is difficult for ESL writing students to provide appropriate feedback, students also believe that giving feedback is not suitable for them because they do not know what they do not know (Hogg, 2018). This view by students was emphasized in a study by Brindley and Scoffield (1998) who indicate that although the participants thought of peer assessment to be very beneficial in increasing their motivation and improving their understanding of the content of the assignment, yet half of them believed that feedback is to be done by a tutor rather than by students.

The different views on the importance of peer feedback show that despite benefits it can bring to ESL learners, there are some constraints to its effectiveness and application in ESL writing classrooms. One of these constraints is students' lack of basic language skills to write error-free and meaningful sentences which is a common challenge for most ESL learners. Another constraint is students' illiteracy of the rules and basis on which they evaluate, criticize, and write feedback for a written work. Yeh, Tseng and Chen (2019) stress on giving students the criteria of how to evaluate their peers' work so that the feedback givers and receivers are aware of their points of strengths and weaknesses in their performance. The importance of students' comprehension of how their writing is evaluated was also emphasized by Zigmond, (2006) who states, "students can see their writing improve if they understand the criteria for evaluation in descriptive categories before they write" (p. 301). 
Another obstacle to web-enhanced peer review is students' sensitivity to sharing their writings online. Research shows that some students feel annoyed from receiving criticism for their written work especially when it is done publicly. Hall (2014) points out that, "uncomfortable dynamics among peers can make young authors vulnerable to teasing and conflict" (p. 28). Likewise, another group of participants in a study by Silva and Moreira, (2003) felt unhappy and uncomfortable because their writings were reviewed online and criticized publicly. Such unpleasant feelings from students can demotivate them to participate effectively in the online discussions and consequently devalue the effectiveness of these platforms in developing students' cognitive and non-cognitive abilities.

To overcome this problem, it is in teachers' capacity to provide a respectful online community for their students. By modelling accepted behavior and polite language for students, they set the foundation of a safe environment that encourages all students to take part effectively on these online platforms. They could also ask students to work together to create and set rules for using these platforms so that the safety and respect for everyone are guaranteed. When the platform has a friendly atmosphere, all students, especially those who are reluctant to take part in discussions are likely to become effective participants.

As Turner \& Pérez-Quiñones, (2009), Papadopoulos, Lagkas and Demetriadis (2012) indicate that peer review stimulates students' higher level of thinking abilities such as analyzing, assessing, and comparing their peers' writing to their own, students also practice some lower-level of thinking abilities like understanding and knowledge during these review sessions. However, teachers should not exclude low achieving students from taking part in peer review activities because frequent exposure to peer review sessions may help them develop their high-level thinking ability at least to revise their own writing and to give feedback in a later stage.

While the availability of the web for students to use at any time and from any place is a remarkable feature, yet it is important that teachers, as suggested by Lee (2010), lead their students during the online peer review sessions. Teachers would be responsible for organizing discussions and monitoring students during their work. Nevertheless, this can be challenging because teachers may not agree to do this extra work in their free time. Therefore, the only way to do online sessions is within the school timing and at school.

For peer review to be effective, students need to be trained on how to give feedback on writing assignments. Whether the feedback is done online or in a traditional classroom, the criterion is nearly the same. For example, teachers can provide students with rubrics, checklists, response grids, and examples to guide the students in the activity (Turner \& Pérez-Quiñones, 2009). This is very important because writing is a creative work, and every student has a different writing style and a different range of vocabulary. Therefore, only good student writers would be able to give critical feedback for their peers. However, since the purpose of peer feedback is to include all students, there must be some way to help all students to give feedback. This help can be in the form of a feedback rubric which can be created cooperatively between the teacher and the students.

Another important factor that affects peer feedback is anonymity. In a study by Rotsaert, Panadero and Schellens (2018) to examine the impact of anonymity on the quality of peer feedback, findings showed that when both feedback givers and receivers were anonymous to each other, there was an increase in the quality of the feedback. However, the study revealed that the quality of peer feedback increases in a non-anonymous but after some time. Thus, teachers can deploy anonymity of users at the beginning of the online writing sessions and when students' responses are of good quality, they can let students use their real names.

\section{Discussions and Conclusion}

The present paper attempted to synthesize literature related to the role web-based technology can play in facilitating peer review in ESL writing classrooms. Findings obtained from reviewing 47 empirical studies show that the use of web-enhanced peer feedback by ESL students improved their writing proficiency and had a positive impact on their motivation to give effective feedback and write for a broad audience. The results also reveal that students who provide feedback for their peers gain a higher level of learning abilities compared to those who only receive feedback whether from their teacher or peer students. Finally, the review asserts the effectiveness of using web-based technology such as blogs and other platforms to motivate students to interact socially with their peer students.

Although, it might be argued that most ESL writing students struggle with their own writing and as a consequence, lack the ability to evaluate and provide correct and effective feedback for their peers, it is noteworthy that the feedback giver or the "expert other" as defined by Green (2005) "does not necessarily 'know' the answers in a traditional sense, but rather is willing to support collaborative learning focused on the 'unknown future" (p. 295). This "unknown future" is students' future writing which is one of the main reasons for giving feedback. 
Thus, ESL writing teachers should not expect their learners to be experts in the field of writing feedback but at least have the potential to interact and take part positively in this social activity which would not only help improve their writing proficiency and their critical thinking abilities but also their "self-reflection and self-efficacy in L2 writing" (Zhang, Song, \& Shen, 2014, p. 670). Furthermore, adapting the web-enhanced approach in giving and receiving feedback among ESL learners would enable students to transfer their learning of the target language from the closed environment of the traditional classroom into the wide classroom of the virtual world where parents, family members and other people can watch and follow up how the student is making progress in their proficiency of the writing skill.

Although research revealed that some students felt uncomfortable and embarrassed from exposing their work online and receiving criticism publicly, web-enhanced peer feedback is in fact preparing these students for their future in which "they will be exposed to open criticism throughout their careers" (Silva \& Moreira, 2003, p. 11). Therefore, teachers should encourage students to accept any negative feedback they receive from their peers about their work since it aims to improve their writing. Teachers have also to set and provide rules that govern the way criticism and evaluation of students' work is done.

As Warschauer and Healey (1998) indicate "when students did not see their work as having any particular social or cultural relevance, they showed little interest in web-based publishing and the medium itself lent little extra legitimacy or authenticity to their writing assignments" ("The World Wide Web," para. "2"). Therefore, the online environment, which the teacher creates or chooses for students to practice peer feedback, should provide students with an opportunity to interact academically and socially with each other in order to motivate them to participate effectively.

In modern schools where technology has infiltrated into ESL classrooms, using web-based platforms can help peer review to be an effective strategy to enhance students' cognitive and noncognitive abilities. Specifically, for ESL writing teachers, findings from this review provide them with an overview of how web-based resources can be utilized to help their ESL students overcome the challenges they face when they write in the target language and promote their ability to think critically. It also informs them about the challenges that their students may encounter during these online sessions such as students' fear of publishing their work and the criticism they might get publicly. Finally, with the rapid advance in technology, new types of web-based platforms are introduced to us, and therefore more research is needed to investigate which types of platforms are more effective than others in facilitating peer review in ESL writing classrooms.

\section{References}

Abdul Latif, M. (2012). Teaching a standard-based communicative English textbook series to secondary school students in Egypt: Investigating teachers' practices and beliefs. English Teaching: Practice and Critique, 11(3), 78-97. https://orcid.org/0000-0003-4002-822X

Brindley, C., \& Scoffield, S. (1998). Peer assessment in undergraduate programmes. Teaching in Higher Education, 3, 79-90. https://doi.org/10.1080/1356215980030106

Buyse, K. (2011). Effective writing tasks and feedback for the Internet Generation. Language Learning in Higher Education, 1(2), 377-398. https://doi.org/10.1515/cercles-2011-0028

Cuseo, J. (2007). The Empirical Case against Large Class Size: Adverse Effects on The Teaching, Learning, and Retention of First year Students. Journal of Faculty Development, 21(1), 1-26.

Dippold, D. (2009). Peer Feedback Through Blogs: Student and teacher perceptions in an advanced German class. European Association for Computer Assisted Language Learning, 21(1), 18-36. https://doi.org/10.1017/S095834400900010X

Elliot, N., \& Williamson, D. (2013). Assessing Writing special issue: Assessing writing with automated scoring systems. Assessing Writing, 18(1), 1-6. https://doi.org/10.1016/j.asw.2012.11.002

Espasa, A., Guasch, T., \& Alvarez, I. (2013). Analysis of Feedback Processes in Online Group Interaction: a Methodological Model. Digital Education Review, 23.

Francisco, J. (2014). Empower ESL Writing Students: Keep It Simple. International Journal of Teaching and Learning in Higher Education, 26(3), 335-342.

Green, P. (2005). Spaces of influence: A framework for analysis of an individual's contribution within communities of practice. Higher Education Research \& Development, 24(4), 293-307. https://doi.org/10.1080/07294360500284607 
Hall, A. (2014). Beyond the Author's Chair. Expanding Sharing Opportunities in Writing. The Reading Teacher, 68(1), 27-31. https://doi.org/10.1002/trtr.1297

Hinkel, E. (2006). Current Perspectives on Teaching the Four Skills. TESOL Quarterly, 40(1). https://doi.org/10.2307/40264513

Hogg, L. (2018). Empowering students through peer assessment: interrogating complexities and challenges. Reflective Practice, 19(3), 308-321. https://doi.org/10.1080/14623943.2018.1437404

Hosseiny, M. (2014). The Role of Direct and Indirect Written Corrective Feedback in Improving Iranian EFL Students' Writing Skill. Procedia - Social and Behavioral Sciences, 98, 668-674. https://doi.org/10.1016/j.sbspro.2014.03.466

Hudelson, S. (1988). Writing in a second language. Annual Review of Applied Linguistics, 9, $210-222$. https://doi.org/10.1017/S0267190500000908

Hyland, K. (2007). Genre pedagogy: Language, literacy and L2 writing instruction. Journal of Second Language Writing, 16, 148-164. https://doi.org/10.1016/j.jslw.2007.07.005

Hyland, K., \& Hyland, F. (2006). Feedback on second language students' writing. Language Teaching, 39(2), 83-101. https://doi.org/10.1017/S0261444806003399

Kline, S., Letofsky, K., \& Woodard, R. (2013). Democratizing Classroom Discourse: the challenge for online writing environments. E-Learning and Digital Media, 10(4). https://doi.org/10.2304/elea.2013.10.4.378

Lakarnchua, O., \& Wasanasomsithi, B. (2013). WHAT IS SAID AND WHAT IS DONE: EFL Student Writers' Perceptions of Peer Feedback Through Blogs and Their Actual Use. Turkish Online Journal of Distance Education-TOJDE, 14(4).

Lee, L. (2010). Fostering reflective writing and interactive exchange through blogging in an advanced language course. ReCALL, 22(2), 212-227. https://doi.org/10.1017/S095834401000008X

Leng, K. (2014). An Analysis of Written Feedback on ESL Students' Writing. Procedia - Social and Behavioral Sciences, 123, 389-397. https://doi.org/10.1016/j.sbspro.2014.01.1437

Lin, W-C, \& Yang, S-C. (2011). Exploring students' perceptions of integrating Wiki technology and peer feedback into English writing courses. English Teaching: Practice and Critique, 10(2), 88-103.

Matamoros-González, J., Rojas, M., Romero, J., Vera-Quiñonez, S., \& Soto, S. (2017). English Language Teaching Approaches: A Comparison of the Grammar-translation, Audiolingual, Communicative, and Natural Approaches. Theory and Practice in Language Studies, 7(11), 965-973. https://doi.org/10.17507/tpls.0711.04

McConnell, J. (2001). Analysis of algorithms: An active learning approach. Burlington, MA: Jones \& Bartlett Publications.

Moate, R. A., \& Cox, J. A. (2015). Learner centered pedagogy: Considerations for application in a didactic course. The Professional Counselor, 5(3), 379-389. https://doi.org/10.15241/rmm.5.3.379

Munoz, C. (2012). Intensive Exposure Experiences in Second Language Learning. Bristol: Multilingual Matters. https://doi.org/10.21832/9781847698063

Otara, A., Uworwabayeho, A., Nzabalirwa, W., \& Kayisenga, B. (2019). From ambition to practice: An Analysis of Teachers' Attitude Toward Learner-Centered Pedagogy in Public Primary Schools in Rwanda. Journal Indexing \& Metrics, 9(1), 1-11. https://doi.org/10.1177/2158244018823467

Papadopoulos, P., Lagkas, T., \& Demetriadis, S. (2012). How to improve the peer review method: Free-selection vs assigned-pair protocol evaluated in a computer networking course. Computers \& Education, 59, 182-195. https://doi.org/10.1016/j.compedu.2012.01.005

Pascarella, E., \& Terenzini, P. (2005). How College Affects Students: Volume 2 A Third Decade of Research. San Francisco: Jossey-Bass.

Phillips, R. (2011). Toward Authentic Student-Centered Practices: Voices of Alternative School Students. Education and Urban Society, 45(6), 668-699. https://doi.org/10.1177/0013124511424107

Platt., N. (1979). Social Context: An Essential for Learning. Language Arts, 56(6).

Poehner, M., \& Infante, P. (2017). Mediated Development: A Vygotskian Approach to Transforming Second Language Learner Abilities. TESOL Quarterly, 51(2). https://doi.org/10.1002/tesq.308 
Rachmayani, A., Rifai, A., \& Rohadi, T. (2018). EXPLORING STUDENTS' RESPONSE TO PEER FEEDBACK STRATEGY IN EFL WRITING CLASS AT STATE SENIOR HIGH SCHOOL 1 SUSUKAN. ELT-Echo, 3(1), 59-69. https://doi.org/10.24235/eltecho.v3i1.2810

Rollinson, P. (2005). Using peer feedback in the ESL writing class. ELT Journal, 59(1), 23-30. https://doi.org/10.1093/elt/cci003

Rotsaert, T., Panadero, E., \& Schellens, T. (2018). Anonymity as an instructional scaffold in peer assessment: its effects on peer feedback quality and evolution in students' perceptions about peer assessment skills. European Journal of Psychology of Education, 33(1), 75-99. https://doi.org/10.1007/s10212-017-0339-8

Silva, E., \& Moreira, D. (2003). WebCoM: A tool to use peer review to improve student interaction. Journal on Educational Resources in Computing, 3(1). https://doi.org/10.1145/958795.958798

Stephanie, Z., \& Lavoie, B. (2011). Addressing Misconceptions about Birth Control: Case Studies Immersing Students in the Facts \& Real-Life Decisions. The American Biology Teacher, 73(6), 353-356. https://doi.org/10.1525/abt.2011.73.6.9

Taylor, S., Ryan, M., \& Pearce, J. (2015). Enhanced student learning in accounting utilizing web-based technology, peer-review feedback and reflective practices: a learning community approach to assessment. Higher Education Research \& Development, 34(6), 1251-1269. https://doi.org/10.1080/07294360.2015.1024625

Truscott, J. (2004). Evidence and conjecture on the effects of correction: A response to Chandler. Journal of Second Language Writing, 13(4), 337-343. https://doi.org/10.1016/j.jslw.2004.05.002

Turner, S., \& Pérez-Quiñones, M. A. (2009). Exploring peer review in the computer science classroom. In Computing Research Repository. Retrieved from https://arxiv.org/ftp/arxiv/papers/0907/0907.3456.pdf

Vavrus, F. (2009). The cultural politics of constructivist pedagogies: Teacher Education Reform in the United Republic of Tanzania. International Journal of Educational Development, 29, 303-311. https://doi.org/10.1016/j.ijedudev.2008.05.002

Warschauer, M., \& Healey, D. (1998). Computers and language learning: An overview. Language Teaching, 31, 57-71. https://doi.org/10.1017/S0261444800012970

Weigle, S. (2011). Assessing Writing. New York, NY: Cambridge University Press.

Whitney, A., Anderson, K., Dawson, C., Kang, S., Rios, E. O., Olcese, N., \& Ridgeman, M. (2012). Audience and Authority in the Professional Writing of Teacher- Authors. Research in the Teaching of English, 46(4), 390-419.

Wildner, S. (1999). Technology Integration into Preservice Foreign Language Teacher Education Programs. CALICO Journal, 17(2). https://doi.org/10.1558/cj.v17i2.223-250

Yeh, H.-C., Tseng, S.-S., \& Chen, Y.-S. (2019). Using Online Peer Feedback through Blogs Promote Speaking Performance. Educational Technology \& Society, 22(1), 1-14.

Zhang, H., Song, W., \& Shen, S. (2014). The effects of blog-mediated peer feedback on learners' motivation, collaboration, and course satisfaction in a second language writing course. Australasian Journal of Educational Technology, 30(6), 670-685. https://doi.org/10.14742/ajet.860

Zigmond, R. (2006). The Numbers Approach to Grading Papers. Teaching English in the Two-Year College, 33(3), 296-304.

\section{Copyrights}

Copyright for this article is retained by the author(s), with first publication rights granted to the journal.

This is an open-access article distributed under the terms and conditions of the Creative Commons Attribution license (http://creativecommons.org/licenses/by/4.0/). 